\title{
Seasonal Incidence of Lemon Butterfly, Papilio demoleus Linn. on Bael
}

\author{
Ram Karan Gaur*, Mukesh Kumar, Sushil Sharma, Narender Singh and B.S. Yadav \\ Chaudhary Charan Singh Haryana Agricultural University, Regional Research Station, \\ Bawal - 123501, Haryana (India) \\ *Corresponding author
}

\begin{abstract}
A B S T R A C T
\end{abstract}
The activity of lemon butterfly $P$. demoleus on bael plant, noticed from first fortnight of

\section{Keywords}

Lemon butterfly, Bael, Population,

Damage,

Pharmaceutical

Article Info

Accepted:

20 July 2018

Available Online:

10 August 2018
July and was found maximum (6.6/10 shoots) in first fortnight of September. The caterpillar population started decline in second fortnight of September (5.45/10 shoots) which continued up to second fortnight of December and completely disappeared in first fortnight of January. The leaf damage varied from 1.60 to 14.20 per cent in different months and maximum infestation (14.20\%) was observed at first fortnight of September, 2016 and after that started decreasing to second fortnight of December. The lemon butterfly exhibited significant and positive correlation with morning relative humidity $(\mathrm{r}=0$. 595) while maximum temperature $(\mathrm{r}=0.345)$, minimum temperature $(\mathrm{r}=0.271)$, evening relative humidity $(\mathrm{r}=0.094)$ and rainfall $(\mathrm{r}=0.033)$ had shown a non significant positive correlation. Correlation between damaged leaves and weather parameters on bael exhibited significant positive correlation $(\mathrm{r}=0.559)$ with the morning relative humidity and non significant positive correlation with maximum temperature $(\mathrm{r}=0.325)$, minimum temperature $(r=0.267)$, evening relative humidity $(r=0.129)$, and rainfall $(r=0.021)$.

\section{Introduction}

Bael ( Aegle marmelos Corea) is a popular indigenous fruit of India, belongs to family Rutaceae . Cultivation of bael is a lucrative venture because of its high pharmaceutical importance. The bael is gaining popularity among the farmers of arid and semi arid areas for economic cultivation. The protein-rich fruits are used in making a very good drink. Mature fruits are astringent, digestive and stomachic and are usually prescribed for diarrhea and dysentery. They are also used as tonic, restorative, laxative and good for heart and brain. The quality of fruits and productivity is lacking due to the infestation of insect pests on vegetative stage as well as fruit formation stage. At vegetative stage lemon butterfly, Papilio demolus (L.) is major and inflicts defoliation of whole plant. About 30 species of insect and mites have been reported feeding on bael in India (Lakra, 2004). Keeping in view its economic importance, the study has been carried out to know the seasonal incidence of lemon butterfly $P$. demoleus on bael during 2016-17. 


\section{Materials and Methods}

Studies were carried out on bael trees grown at Regional research station Bawal from June 2016 to February 2017. The incidence of pest was recorded at fortnightly intervals on five randomly selected bael tree. Ten shoots of approximately $20 \mathrm{~cm}$ length were randomly selected from all the directions from each tree for recording observations. The damaged leaves per shoot was worked out and expressed as per cent damage of leaves per shoot. The selected plants were kept free from application of any insecticide throughout study period for recording of observations. From each tree, the data on larval population of citrus caterpillar were taken at fortnightly interval. These studies also provide information about the favourable periods for pest build up that help in the management of the pest. The weather parameters viz., maximum temperature and minimum temperature, morning relative humidity, evening relative humidity and rainfall were recorded on daily basis from June, 2016 to January, 2017. Correlation analysis was made for the data on different abiotic parameter with the damage and population of lemon butterfly.

\section{Results and Discussion}

The results revealed that the activity of lemon butterfly $P$. demoleus on bael plant noticed from first fortnight of July, 2016 and thereafter its population goes on increasing up to mid of September, 2016. The population of lemon butterfly, during the period of study was found maximum (6.6/10 shoots) in first fortnight of September. The caterpillar population started decline in second fortnight of September (5.45/10 shoots) which continued up to second fortnight of December and completely disappeared in first fortnight of January, 2017. The lemon butterfly exhibited significant and positive correlation with morning relative humidity $(\mathrm{r}=0.590)$ while maximum temperature $(\mathrm{r}=0.345)$, minimum temperature $(\mathrm{r}=0.271)$, evening relative humidity $(\mathrm{r}=0.094)$ and rainfall $(r=0.033)$ had shown a non significant positive correlation. The present findings are in close conformity with the reports of Surpur et al., (2014) who reported that seasonal incidence of lemon butterfly started from July and continued till December month on sweet orange. The findings of the present investigation were also similar with the studies of Ganguli and Ghosh (1967) who reported that the occurrence of butter flies was noticed in the months of June, August and November when there were low temperature and high relative humidity prevailed. The results of present findings are more or less similar with Maheswara Babu (1988) who reported that the population of P.demoleus was present in June-July and reached its maximum in the months of August and September, from October onwards the pest population declined. Sahu et. al. (2015) observed maximum population of citrus butterfly during the month of September.Thakare and Borle (1969) stated that the caterpillars of $P$. demoleus besides citrus, damaged bael (Aegle marmelos), Kadhu limb (Murraya koenigii), bawachi (Psoralea corylifolia) and bhira (Chloroxylon sweitenia) and further reported that the pest caused 100 percent defoliation in Maharashtra. The present finding is in concurrence with the finding of Jahnavi et. al.,(2018) who studied the seasonal incidence of citrus butterfly, Papilio demoleus L. on acid lime and reported that evening relative humidity (0.497) showed positive significant association with butterfly larval population in citrus during 2015-16.

The damaged leaves due to caterpillar of lemon butterfly were noticed for the first time during first fortnight of July at the minimum temperature of $26.5{ }^{\circ} \mathrm{C}$ and maximum 
temperature of $35.4^{0} \mathrm{C}$, morning relative humidity 76.5 per cent and evening relative humidity 53.5 per cent. The maximum $(14.20 \%)$ leaves infestation was observed in first fortnight of September, 2016 on bael when maximum temperature was $32.7^{\circ} \mathrm{C}$ and minimum $24.9^{\circ} \mathrm{C}$, morning relative humidity 87.3 per cent and evening relative humidity 55.3 per cent. The infestation started decreasing from second fortnight of
December, 2016 and reached minimum $(2.2$ $\%)$ in $2^{\text {nd }}$ fortnight of December 2016. Correlation between damaged leaves and weather parameters on bael exhibited significant positive correlation $(\mathrm{r}=0.559)$ with the morning $\mathrm{RH}$ and non significant positive correlation with maximum temperature $(\mathrm{r}=0.325)$, minimum temperature $(\mathrm{r}=0.267)$, evening relative humidity $(\mathrm{r}=0.129)$, and rainfall ( $\mathrm{r}=0.021)$ (Table 1 and 2).

Table.1 Population dynamics and per cent infestation of lemon butterfly on bael in 2016-17

\begin{tabular}{|c|c|c|c|c|c|c|c|}
\hline \multirow[t]{2}{*}{ Fortnight } & \multicolumn{2}{|c|}{ Temperature } & \multicolumn{2}{|c|}{ Relative Humidity } & \multirow{2}{*}{$\begin{array}{c}\text { Rainfall } \\
\text { mm }\end{array}$} & \multirow{2}{*}{$\begin{array}{c}\text { Leaves } \\
\text { Infestation } \\
(\%)\end{array}$} & \multirow{2}{*}{$\begin{array}{l}\text { Caterpillar } \\
\text { Population/ } \\
\text { Ten shoots }\end{array}$} \\
\hline & $\begin{array}{l}\text { Max. } \\
\text { Temp. }\end{array}$ & $\begin{array}{l}\text { Min. } \\
\text { Temp. }\end{array}$ & $\begin{array}{c}\text { Morning } \\
(\%)\end{array}$ & $\begin{array}{c}\text { Evening } \\
(\%)\end{array}$ & & & \\
\hline June I & 35.8 & 26.7 & 74.5 & 57.0 & 82.3 & 0 & o \\
\hline July I & 35.4 & 26.5 & 76.5 & 53.5 & 63.9 & 1.6 & 0.6 \\
\hline July II & 33.4 & 26.8 & 86.5 & 65.5 & 35.6 & 3.5 & 2.8 \\
\hline August I & 32.4 & 26.1 & 86.0 & 72.5 & 222.2 & 6.0 & 3.9 \\
\hline August II & 34.6 & 25.8 & 85.0 & 59.5 & 66.3 & 8.3 & 5.6 \\
\hline September I & 32.7 & 24.9 & 87.3 & 55.3 & 50.2 & 14.2 & 6.6 \\
\hline September II & 35.3 & 21.6 & 80.0 & 36.5 & 13.4 & 12.0 & 5.45 \\
\hline October I & 36.8 & 18.4 & 74.0 & 38.5 & 0 & 9.2 & 4.8 \\
\hline October II & 35.5 & 15.3 & 73.0 & 16.5 & 0 & 6.5 & 4.4 \\
\hline November I & 30.1 & 12.3 & 72.6 & 24.3 & 0 & 5.9 & 3.4 \\
\hline November II & 26.7 & 7.4 & 73.0 & 18.5 & 0 & 4.3 & 3.2 \\
\hline December I & 20.0 & 8.4 & 74.5 & 28.5 & 4 & 3.6 & 2.8 \\
\hline December II & 25.0 & 6.1 & 69.0 & 32.0 & 0 & 2.2 & 1.4 \\
\hline January I & 21.1 & 4.2 & 93.5 & 47.0 & 4.6 & 0.0 & 0.0 \\
\hline
\end{tabular}

Table. 2 Correlation coefficient between abiotic factor and caterpillar of lemon butterfly population and infestation

\begin{tabular}{|l|l|c|c|}
\hline S/No. & Abiotic factor & Infestation & Citrus caterpillar population \\
\hline & & $0.325^{\mathrm{N}}$ & $0.345^{\mathrm{NS}}$ \\
\hline $\mathbf{2}$ & Min. Temperature & $0.267^{\mathrm{NS}}$ & $0.271^{\mathrm{N}}$ \\
\hline $\mathbf{3}$ & Morning R.H. & $0.559^{*}$ & $0.590^{*}$ \\
\hline $\mathbf{4}$ & Evening R.H. & $0.129^{\mathrm{NS}}$ & $0.094^{\mathrm{NS}}$ \\
\hline $\mathbf{5}$ & Rainfall & $0.021^{\mathrm{NS}}$ & 0.033 \\
\hline
\end{tabular}


Population dynamics and per cent infestation of Lemon Butterfly in bael
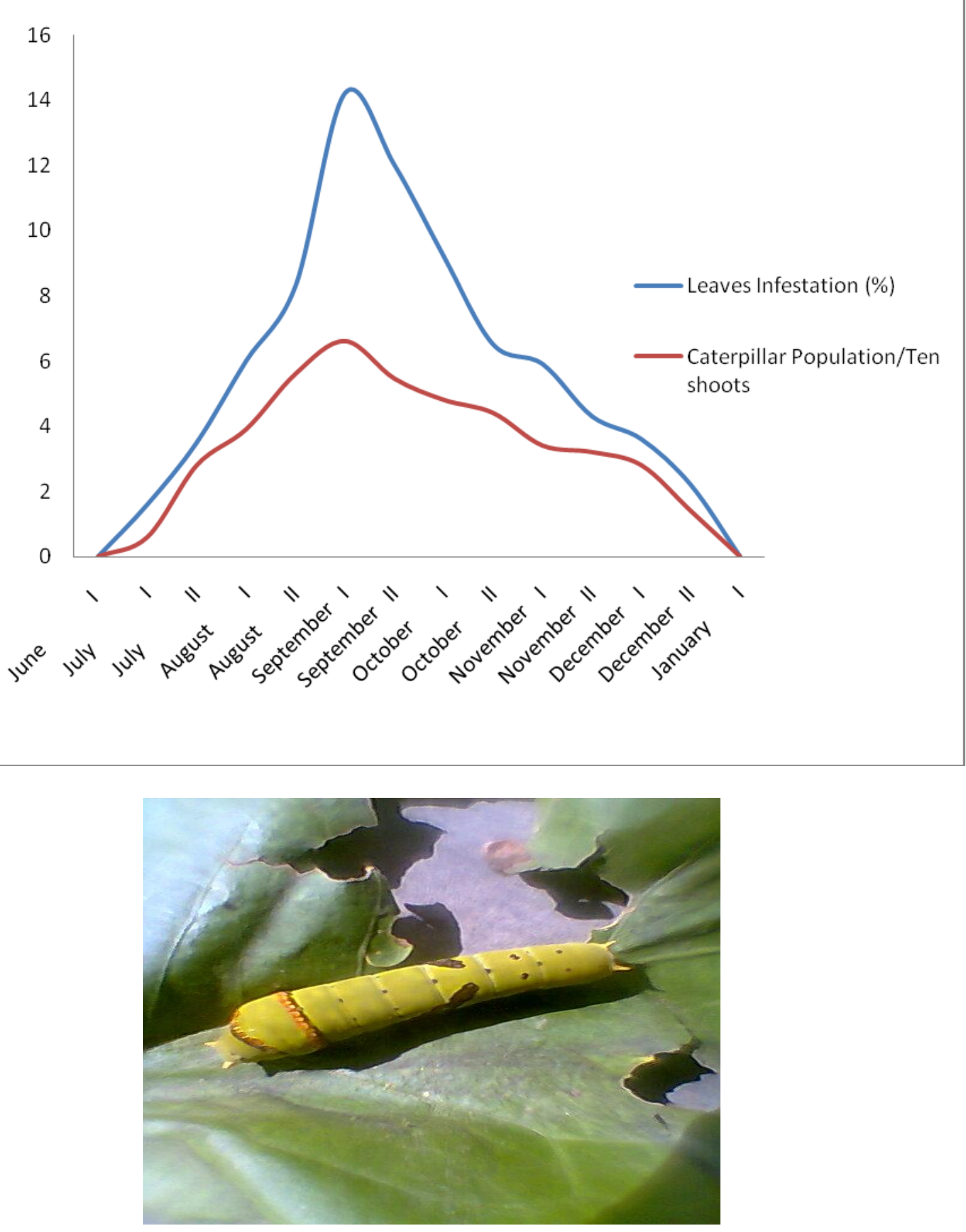

Caterpillar of $P$. demoleus on bael leaf

The percent findings are in agreement with Narayanamma and Savitri (2002) where the peak activity of lemon butterfly was noticed during August month. Ram Pratap et al., (2000) reported that maximum damage by $P$. demoleus on lime in the Bundelkhand region 
of Uttar Pradesh was occurred from August to September. The results of present findings are also in agreement with Sharavan et al., (2010), Ram et al., (2000) who reported that infestation caused by $P$. demoleus was in peak during August to September.

\section{References}

Ganguli, R.N and Ghosh, M.R.(1967). Biology of $P$. demoleus pest of citrus in Tripura state. Indian Agriculturist. 11: 13- 18

Jahnavi, M., Ramakrishna, A. Rao and Sarada, G. (2018). Seasonal incidence of Citrus Butterfly, Papilio demoleus Linnaeus (Lepidoptera: Papilionidae) in acid lime. International Journal of Current Research in Life Sciences Vol. 07, No. 02, pp.969-972, February, 2018.

Maheshwarababu, P. (1988). Biology and chemical control of citrus butterfly $P$. demoleus Linnaeus (Lepidoptera: Papilionidae). M.Sc (Ag.) Thesis. Andhra Pradesh Agricultural university, Hyderabad. 117.

Ram, P., Pal, R. K. and Singh, J. (2000). Incidence of Lemon Butterfly, Papilio demoleus on citrus", Annals of plant protection sciences Vol. 8(2):245-246.
Sahu, C.M., Nirala, Y.P.S., Painkra, K.L and Ganguli, J.L. (2015). Seasonal incidence of Citrus Butterfly, Papilio demoleus Linnaeus (Lepidoptera: Papilionidae) on curry leaf, Murraya koenigii at Raipur. International Journal of Tropical Agriculture 33(2): 525-528.

Shravan, M. H., Karuppaiah, V., Sharma, S. K.and Sing, R. S.(2010) .Population dynamics of lemon butterfly (Papilio demoleus) in bael (Egle marmelos) as influenced by abiotic factors in arid region Rajastan, Indian journal of Arid Horticulture Vol. 5(1-2): 50-52.

Shwetha, Surpur., Hosamani, A. C., Jamuna, B. Latha, H. C.and Geeta,S. (2014). Seasonal incidence of Lemon Butterfly, Papilio demoleus Linn and its parasitiod, Apanteles angaleti (muesebeck) on sweet orange in north eastern dry region of Raichur. Life Sciences International Research Journal Vol. 1 (1) :414-420

Thakare, K. R. and Borle, M. N.( 1969). Survey report of damage caused by lemon butterfly pest in Vidharbha region. Official communication vide Do No. 782/69 dt. 26.08.1969.

\section{How to cite this article:}

Ram Karan Gaur, Mukesh Kumar, Sushil Sharma, Narender Singh and Yadav, B.S. 2018. Seasonal Incidence of Lemon Butterfly, Papilio demoleus Linn. on Bael. Int.J.Curr.Microbiol.App.Sci. 7(08): 3760-3764. doi: https://doi.org/10.20546/ijcmas.2018.708.382 